\title{
Indonesian EFL Students' Perspective on Writing Process: A Pilot Study
}

\author{
Imelda Hermilinda Abas (Corresponding author) \\ Universiti Utara Malaysia, College of Arts and Sciences, 06010 Sintok, Kedah, Malaysia \\ E-mail: imelabas@yahoo.com
}

Noor Hashima Abd Aziz

Department of Language Studies, School of Education and Modern Languages, Universiti Utara Malaysia, College of Arts and Sciences, 06010 Sintok, Kedah, Malaysia

E-mail: noor934@uum.edu.my

Doi:10.7575/aiac.alls.v.7n.3p.21

URL: http://dx.doi.org/10.7575/aiac.alls.v.7n.3p.21
Received: 08/01/2016

Accepted: 21/02/2016

\begin{abstract}
The study was aimed at understanding the EFL Indonesian students' perspective on the writing process. The pilot study involved two male Indonesian postgraduate students in Universiti Utara Malaysia. The Indonesian students were selected based on the following criteria: (1) had enough knowledge in English writing, indicated by the completion of Academic Writing and Research Methodology courses taken in UUM; (2) had written an unpublished thesis during their undergraduate studies in Indonesia and they are writing their master or doctoral thesis in English; (3) used English extensively in writing their assignments, and in daily activities. Pseudonyms were used to refer to the participants as Sukarno and Suharto. The data were collected through in-depth interviews with the participants. The interview sessions took approximately 15-20 minutes for each participant and were videotaped and audiotaped. Semi-structured interview with 15 questions and probes were used. The results showed that the two participants had positive feelings and attitudes towards writing in English. Although they had a hard time in English writing during their undergraduate in Indonesia, they become fond of writing in English in their postgraduate time due to the exposure to English extensively. In composing, they used brainstorming, drafting, pausing, revising and editing in a recursive manner.
\end{abstract}

Keywords: in-depth interview, pilot study, writing process, English as a Foreign Language (EFL)

\section{Introduction}

Most English as a foreign language (EFL) students find writing in English to be difficult because they have to use the correct English grammar and vocabulary, apply the writing skills they have learnt, and incorporate these knowledge with their previous experience on the topic given when writing. In relation to the research conducted, the researcher, herself, faced the challenge of writing her doctoral thesis in English. The researcher has discovered that writing is a complex process and recursive in nature, whereby a writer shifts from one stage to another and might shift back to the beginning or the previous part naturally. This paper is on the pilot study of a dissertation that the researcher conducted in order to understand the EFL Indonesian students' perspective on the writing process.

Let us begin with the definition of writing. Bereiter and Scardamalia (1987) define writing as "a way for students in all content areas to make meaning for themselves" (p. 5). In addition, Herrington (1985) associates writing with learning to think and exchanging information in their particular domains. Writing is one of the four aspects of language in English beside listening, speaking and reading. It is essential particularly in the $21^{\text {st }}$ century, in the education context to be successful professionals (Applebee, Langer, Mullis, Latham \& Gentile, as cited in Hamman, 2005; Johannesen, 2001).

What makes writing so different from the other skills such as listening, speaking and reading? Speaking and listening are acquired naturally for the first and second language learners because they are required to communicate using the target language. Thus, speaking may obviously show the students' language acquisition level (Peng, 2001). Contrary to speaking and listening, which mostly consist of frustration-free activities, writing is less preferred and difficult because it is complicated and demands higher thinking abilities (Alhosani, 2008).

In the academic setting, students are required to do their writing tasks such as assignments, reports, thesis and dissertation. A growing number of research provide insights into the importance of writing for academic success. Bjork and Raisanen (1997) point out that writing is important because of its useful function as a tool for language development in all disciplines. Moreover, Bruning and Horn (2000) suggest writing as a "critical tool for intellectual and social development" (p.30).

If writing is so important, then why is it difficult? Factors that are associated with writing problems in second language or foreign language are different cultural background (Imtiaz, 2003; McCharthy, 1992; Sadik, 2009), different textual 
patterns (McCharthy, 1992) and types of writing (process and product of second language (L2) writing) such as language competence, first language (L1) writing competence, use of cohesive devices, metacognitive knowledge about writing task, writing strategies and writer's personal characteristics (Angelova, 1999). Some studies on the EFL students in Arab setting (Bacha, 2002; Kharma \& Hajjaj, 1997; Rababah, 2003), found that a serious problem in writing hindered the EFL learners' academic progress. They reported that the English language skills in general and writing skill in particular were lacking among the Arab students. Moreover, the teachers were faced with the challenge of developing their students' writing skill because they were not aware of the writing processes, skills and knowledge that are involved in planning, drafting and revising a text.

Similarly, most university students in Indonesia find it difficult to express their ideas in English, particularly in academic writing, despite the fact that they have learnt English since elementary school. A study conducted by Sadik (2009) on Indonesian university students found that pre-writing, planning, drafting, revising and editing were the stages of writing that were taught to the students. However, she discovered that problems in writing were associated with limited knowledge of writing strategies, problem with grammatical structure, and low interest in writing. She also discovered that the students did not realize that writing is time consuming and tedious.

In addition, Mistar, Zuhairi and Parlindungan (2014) conducted a study on secondary school students and found that the students lacked in the knowledge of writing. The students were found to use self-monitoring strategies, and correct their mistakes by reading, rewriting, noticing mistakes and paid a great deal of attention to linguistic aspects of English, which occurred only at the editing phase. Moreover, a study done by Setyono (2014) on the teaching of writing at the high school level, found that the product-based approach of writing instruction was still being practiced in most schools. It was found that the students were not given ample time to write to produce a final product of writing through revising process. It can be assumed from these studies (Mistar et.al., 2014, Sadik, 2009, Setyono, 2014), that the lack of knowledge in writing for most of the Indonesian university students can be associated with their previous education background, limited knowledge of writing, and not given enough time to practice writing. These findings inspired the researcher to explore the writing process from the EFL Indonesian students' perspectives.

\section{The Teaching of Writing}

The approaches in English as a second language (ESL) and EFL writing pedagogy have developed from productoriented (i.e. the controlled composition approach and the current-traditional rhetoric approach) to a process-oriented approach. The focus of a product-oriented approach is on the final product of the writing. However, since the 1970s, the teaching of writing has shifted its focus from the written product to a concentration on the writer and the writing process (Silva, 1990; Reid, 1993). Writing process is defined as "a series of operations leading to the solution of a problem. The process begins when a writer consciously or unconsciously starts a topic and is finished when the written piece is published" (Graves, 1983, p. 4).

In early 1982, Berlin introduced a developed model of writing that focuses on the process composing elements, that is, paying more attention to writer, reader, authenticity and language in written text. This model served as a basis in understanding the progress in second language (L2) writing theory. Researchers have adopted the research on the native English speaker's writing process in their ESL research, focusing on how the writers compose and understand writing as a process of discovery and self-expression (Zamel, 1976, 1982). For example, a study on the college students' writing process conducted by Flower and Hayes (1981), discovered that the students' writing process was recursive rather than linear.

Moreover, Silva (1990) asserts that the process approach in L2 writing consists of systematical, persistent and contextual aspects, which include building and applying of knowledge in an encouraging classroom atmosphere for students to complete their writing. Thus, the focus in writing L2 instruction is on the L2 writer, L1 audience, L2 text, L2 writing context, and interaction of these components in different ESL context. This implies that the teaching of L2 writing should be based on a comprehensive concept of L2 writing contribution to the writer, reader, text, and context (Silva, 1990).

In the process approach classroom, the purpose of instructional activities is to allow the students to express themselves fluently, think and organize their ideas before writing and revising drafts. The teachers are encouraged to form collaborative learning such as peer responses and group works, loosen their authority and engage in a less controlling role by allowing the students to select their own topic, and letting them to work at their own pace. Moreover, the sense of audience is also regarded as one of the significant features as the students are encouraged to have their voice in their writing, while simultaneously paying attention to the audience.

In the Indonesia context, the approaches of controlled composition, where learning to write in English is mainly through teacher-directed instructional approach with an emphasis on the students' final writing products, are still practiced at the school and university levels (Ignatius, 1999; Latief, 1990; Sulistyaningsih, 1997). Sadik (2009) argues that "this emphasis should be totally changed to an emphasis on process of writing in the teaching and learning process" (p.127). Generally, the students are taught useful vocabulary, sentence patterns, and how to use conjunctive devices to connect sentences to form a paragraph and connect discourses between paragraphs. Then, they apply such linguistic knowledge to the assigned writing task. The knowledge of rhetorical patterns is introduced through modeled essays/compositions. 


\section{Methodology}

\subsection{Participants}

The selection of the participants in a qualitative study is based on non-probability sampling where the researcher selects individuals because "they are available, convenient, and represent some characteristics the investigator seeks to study" (Creswell, 2012, p. 145).

For this pilot study, the researcher employs purposive sampling to select postgraduate students as participants for this study through careful considerations based on the following criteria: (1) they were considered to have enough knowledge in English writing, indicated by the completion of Academic Writing and Research Methodology courses; (2) they had written an unpublished thesis during their undergraduate studies and they are writing their master or doctoral thesis in English as a prerequisite to complete their master or PhD degree; (3) they used English extensively in the class, that is writing their assignments, and in daily activities.

For this pilot study, two male Indonesian, Master and $\mathrm{PhD}$ students in UUM, were selected as the participants. Pseudonyms were used to refer to the participants as Sukarno and Suharto. The purpose of using pseudonym was to make the participants feel comfortable in answering the interview questions. The interviews were conducted in English. The participants were able to understand all the questions and the interviews were recorded in order to help the researcher in transcribing the interview. The responses from the participants helped the researcher to find the themes or categories that might emerge in the actual research and to refine the interview questions where necessary. Reasons for conducting the pilot interview were to familiarize the researcher with the interviewing technique and questions, to make sure that the interview questions were clear and understandable, and to create the circumstantial suitability of the situations in getting the participants' responses (Creswell, 2012).

\subsection{Data Collection}

The data were collected through in-depth interviews with the two participants. The interview session was conducted face-to-face with each participant. The nature of the in-depth interview was to understand in details about the participants' experiences going through the writing process. The interview session took approximately 15-20 minutes for each participant and was videotaped and audiotaped. Semi-structured interview with 15 questions and probes were used. The interview questions can be seen in the Appendix. The interview questions were adapted from Alhosani (2008).

\subsection{Data Analysis}

In terms of analyzing the interview data, the researcher followed some steps suggested by Cohen, Manion and Morrison (2007), and adapted some from Alhosani (2008). The steps were: (1) the recorded interviews were transcribed as soon as the researcher finished the interview; (2) the researcher read the interview transcripts carefully, repeatedly, and coded, classified, and categorized the responses to the interview questions; (3) the researcher looked for repetition of words, phrases, and sentences as well as positive or negative reactions to the interview questions or any frustrating aspects of writing a composition; (4) the researcher drew conclusions and verification of data where the data were displayed and interpreted. After applying the above steps, the researcher classified the interview data into three themes: (1) feelings and attitude towards writing; (2) learning experience in writing; and (3) knowledge about the writing process. In analyzing the data, all the recorded interviews were transcribed and crosschecked with the note-taking.

\section{Findings}

\subsection{Sukarno}

The first interview was conducted with Sukarno who was a Master student at the College of Arts and Sciences, Universiti Utara Malaysia. He graduated from a private university in Jakarta in 2011.

\subsubsection{Feelings and Attitudes towards Writing in English.}

In responding to the researcher's question regarding his feelings towards writing in English, Sukarno stated that as a master student, he had to write in English almost every day for his assignments, project paper, and other academic purposes. Sukarno claimed that he liked writing in English because he enjoyed constructing the sentences and paragraphs in English, which is an important part of writing. He stated that he preferred to write in English than to write in his mother tongue. However, he was not confident writing in English because he thought that he was not a proficient writer yet.

\subsubsection{Learning Experience in Writing}

In replying to questions related to learning experience, Sukarno stated that he attended some writing classes during his undergraduate study in Indonesia. However, he was not aware about terms such as writing strategies and writing process, because his teacher did not mention or introduce the terms to the students. Sukarno explained that when he was taking the composition class, the teacher taught that writing should consist of introduction, body and conclusion paragraphs. He also learnt that in writing a paragraph, a writer should consider the unity of a paragraph, coherence, and how to link each paragraph. To generate initial ideas, he used brainstorming. He applied these strategies to his writing.

\subsubsection{Knowledge about the Writing Process}

A few interview questions were asked in relation to the knowledge about the writing process category. For instance, when the researcher asked questions on the stages that Sukarno used in writing, he replied that he used brainstorming, 
building outline of the writing, writing the introduction, body and conclusion paragraphs, revising, editing, and submitting the paper to the teacher. Sukarno further explained that when given a topic to write, he would firstly search for information related to the topic through brainstorm activity, associate or visualize the words with the topic, and only then he would start to write.

While composing the essay, and running out of ideas, he explained that he would pause for a while to read his work and to search for more relevant information to develop his ideas. He would also read his work for editing purpose by looking for errors in grammar and word choice.

After finishing the first draft, Sukarno would go through another pausing stage aimed at editing and revising. Sukarno stated that he would reread the draft thoroughly, word by word, looking for grammar and spelling errors, revising sentences with ambiguity meanings, checking for coherence in ideas, and adding or deleting ideas. He considered these stages as important because his ideas should be written clearly so that the reader could understand what he wanted them to understand from his writing. He also admitted that he wrote drafts, revised, and edited his work for more than one time. When Sukarno was satisfied with his writing, he would hand-in his work and wait for feedback from the teacher. The teacher would correct his writing by giving him feedbacks on the grammar and vocabulary.

\subsection{Suharto}

The second interview was conducted with Suharto who was a $\mathrm{PhD}$ student at the College of Business in Universiti Utara Malaysia. He graduated from a private university in Jakarta in 2011. As a PhD student he had to write in English for his dissertation. He used English in his daily activities.

\subsubsection{Feelings and Attitudes towards Writing in English}

Suharto's responses to the questions regarding his feelings and attitudes towards writing in English and his feelings towards writing in English were positive. Suharto considered English to be important because it was used in his daily activities in UUM and in writing his dissertation. Thus, he preferred to write in English rather than his mother tongue. However, in the past, he was frustrated with his result in the writing component when he sat for International English Language Testing System (IELTS). He obtained 6.5 writing band score out of 9. Although he had already given his $100 \%$ effort, he could not achieve his target score. At that time, he thought that writing was very difficult because he did not have enough time to practice English in Indonesia. However, to develop his writing skill, he would mark new words with highlighter while reading and then find the meanings by referring to a dictionary. As a result, when his writing skill has improved, he started to like writing since he is exposed to English in his daily activities.

\subsubsection{Learning Experience}

Suharto's responses to the questions regarding his learning experience and knowledge on writing were positive. When the researcher asked Suharto about his learning experience in writing in English, he replied that during his undergraduate degree in Indonesia, he was not aware of his writing strategies. However, during his master degree in Indonesia, he learnt English intensively as most of the courses were delivered in English language, and all the assignments were written in English. Thus, his writing improved. He developed his writing through grammar study, for example, the study of collocation and paraphrasing. Nevertheless, he admitted that he was not a skillful writer yet. In the past, Suharto joined an IELTS preparatory class where the teacher taught him how to write by emphasizing on the maximum number of words, the nature of English words (collocation, paraphrasing), and word choice. Most of the activities in the class were related to grammar and strategies on how to develop arguments in writing.

\subsubsection{Knowledge about the Writing Process}

Suharto's responses to the questions regarding the stages of writing process he used in his composition and when facing problems in writing were positive. When the researcher asked about the stages of writing process that Suharto used in his writing, he replied that firstly, for example, writing about a company, he would follow the timeline or the history of the company. Next, he would write about it narratively. Then, he would reread what he had written to check the flow and to make any necessary changes.

When Suharto was given a topic to write, he would brainstorm for keywords and search relevant information on the topic to present his ideas. Then, he would start writing immediately. Most of the information he gathered from the internet. He added that it was important for him to get information on the topic before making his stand.

When running out of ideas, Suharto would pause, take a break for a while and discuss his difficulties with his colleagues or friends to get some fresh ideas. The pausing stage also occurred with editing and revising purposes. The editing and revising stages were done more than once by rereading and checking for errors in grammar, punctuation, and word choice. Before handing-in his writing, Suharto would edit it by printing out the written text, read it carefully, word for word, to make sure that the draft was error free. The teacher mostly corrected his writing in the grammar part.

\section{Discussion}

From the pilot interviews, the researcher found that the Indonesian participants were able to understand the interview questions clearly. When answering the interview questions, they used English language. Both participants used English in Universiti Utara Malaysia because they had to communicate with many international students there. They used English in their daily activities and in their writing for academic purposes.

Sukarno and Suharto had positive feelings and attitudes towards writing in English and their experiences in writing in English. Sukarno and Suharto had attended some writing classes during their undergraduate and master studies. 
However, their teachers did not mention or introduce the terms of writing process to them. Their teachers only explained that writing should consist of introduction, body and conclusion paragraphs and that in writing a paragraph, a writer should consider about the unity of a paragraph, coherence, and how to link each paragraph. In addition, when the participants were taking master or $\mathrm{PhD}$ degree in UUM, they started to like writing in English. For them, writing was fun and enjoyable because writing involves grammar, building the words into sentences and into paragraphs. Both considered writing in English as important because they wrote their assignments, papers or dissertation in English. The two participants used English in their daily activities because they needed to communicate with international students in UUM. Thus, they both had the opportunity to practice English, in spoken and written form. Therefore, it is important to note that the connection between environment and the opportunity to practice English is important for second language learners. This can be linked to the Affective Filter Hypothesis (Krashen, 1994) and Universal Grammar Hypothesis (Chomsky, 1986), where the exposure to the target language and the environment where the language is practiced are essential parts for second language learning.

In terms of the participants' knowledge about the writing process, they used brainstorming, drafting, pausing, revising and editing in a recursive order. However, each stage had different purpose. For instance, Sukarno used brainstorming to find information related to the topic and by associating or visualizing the brainstormed words that he found related to the topic. The pausing stage aimed at finding more relevant information to develop his ideas and for editing and revising purposes. He paused when he ran out of ideas, and read carefully, word by word, what he had written by looking for errors in grammar and searching for the correct words to use, revising sentences with ambiguity meanings, and checking for coherence in ideas. Although each participant went through each stage with a different purpose, it could signify how the writing process develops in general. This implies that "students revise as they draft, they plan as they edit; and so forth" (Williams, 2003, p. 120). Moreover, Williams (2003) suggests that all writers experience these processes to some extent, however, what may work for one writer, might not work for another.

Suharto used brainstorming to find some relevant information from the internet and to understand the ideas and the problems. The pausing stage occurred with some purposes: (1) to discuss his difficulties in writing with his colleagues or friends to get more ideas; (2) to edit and revise by rereading and checking for errors in grammar, punctuation, and word choice. The result of the pilot study can be associated with Alhosani's (2008) study where she found that the writing process approach was identified as a useful method for ESL students, regardless of their English proficiency to improve their writing skills. The findings of this pilot study can also be linked to Flower and Hayes's (1981) findings where the writing process (planning, translating, reviewing) that the students used was recursive as they were writing.

\section{Conclusion}

This study explored the writing process from the perception of two male EFL Indonesian students studying in UUM. The selection of the participants was based on purposive sampling and some characteristics, such as: (1) they were assumed to be good in writing in English indicated by the fulfillment of academic writing and research methodology courses; (2) had written an unpublished thesis during their undergraduate in Indonesia, and were doing a master or doctoral thesis in English in UUM. Pseudonyms were used to refer to the participants as Sukarno and Suharto.

The data of this pilot study were collected through in-depth interviews with the two participants. The in-depth interview was used to understand in details about the participants' experience, in this case, the process of applying the writing process. In analyzing the data, all the recorded interviews were transcribed. The interview sessions took approximately 15-20 minutes for each participant and were videotaped. In analyzing the interview transcripts, the researcher classified the interview data into three categories: (1) feelings and attitude towards writing; (2) learning experience in writing; and (3) knowledge about writing process.

The results showed that both Sukarno and Suharto had positive feelings and attitudes towards writing in English. The learning experiences of both participants were varied. During their undergraduate studies, both participants attended some writing classes. However, they were not aware of the writing strategies and writing process because their teacher did not mention or introduce the terms to them. Regarding the writing process they used in composing, both participants used brainstorming, drafting, pausing, revising and editing in recursive order.

\section{References}

Alhosani, N.M. (2008). Utilizing the writing process approach with English as a second language writers: A case study of five fifth grade of ESL Arab students (Doctoral dissertation). Retrieved from ProQuest Dissertation and Thesis. (3341499).

Angelova, M. (1999). An Exploratory Study of Factors Affecting the Process and Product of Writing in English as a Foreign Language. Buffalo, NY: State University of New York.

Bacha, N. N. (2002). Developing learners' academic writing skills in higher education: A study for educational reform. Language \& Education, 16(3), 161-177. DOI: 10.1080/09500780208666826

Bereiter, C., \& Scardamalia, M. (1987). The psychology of written composition. Hillsdale, NJ: Lawrence Erlbaum.

Bjork, L., \& Raisanen, C. (1997). Academic writing: A university writing course. Lund, Sweden: Studentlitteratur.

Bruning, R., \& Horn, C. (2000). Developing motivation to write. Educational psychologist, 35(1), 25-37. DOI: $10.1207 / \mathrm{S} 15326985 \mathrm{EP} 3501 \_4$ 
Chomsky, N. (1986). Barriers. Linguistic Inquiry Monograph Thirteen. Cambridge: M.I.T. Press.

Cohen, L., Manion, L., \& Morrison, K. (2007). Research method in education. UK: Routledge.

Creswell, J. W. (2012). Educational research: Planning, conducting and evaluating quantitative and qualitative research ( $4^{\text {th }}$ Ed.). Boston, M.A : Pearson Education Inc.

Flower, L. S., \& Hayes, J. R. (1981). A cognitive process theory of writing. College Composition and Communication, 32, 365-387. DOI: $10.2307 / 356600$

Hamman, L. (2005). Self-regulation in academic writing tasks. International Journal of Teaching and Learning in Higher Education, 17(1), 15-26. Retrieved from http://www.isetl.org/ijtlhe/pdf/IJTLHE14.pdf

Herrington, A. J. (1985). Writing in academic settings: A study of the contexts for writing in two college chemical engineering courses. Research in the Teaching of English, 331-361. Retrieved from http://www.jstor.org/stable/40171066

Ignatius, H. (1999). English academic writing features by Indonesian learners of English (Unpublished Doctoral Dissertation). Graduate Program of State University of Malang, Indonesia.

Imtiaz, S. (2003). Cognitive processes in writing: Exploring the strategies used by second and foreign language learners of English [monograph]. Language in India, 3 (4 April, 2003). Retrieved from http:// languageinindia.com /april2003/cognitivewriting.html

Johannesen, L.R. (2001). Teaching thinking and writing for a new century. English Journal, 90, 38-46. DOI: $10.2307 / 822054$

Kharma, N., \& Hajjaj, A. (1997). Errors in English among Arabic speaker. Beirut: Librairie du Liban.

Krashen, S.D. (1994). Bilingual education and second language acquisition theory. In Bilingual Education Office (Ed.) Schooling and language-minority students: A theoretical framework ( $2^{\text {nd }}$ ed., pp. 47-75). Los Angeles, CA: California State University. Evaluation Dissemination and Assessment Center.

Latief, M. A. (1990). Assessment of English writing skills for students of English as a foreign language at the Institute of Teacher Training and Education IKIP Malang, Indonesia (Doctoral dissertation, University of Iowa). Retrieved from: ProQuest Dissertation and Thesis.

McCharthy, M. (1992). Discourse analysis for language teacher. Cambridge, UK: Cambridge University Press.

Mistar, J., Zuhairi, A., and Parlindungan, F. (2014). Strategies of learning English writing skill by Indonesian senior high school students. Arab World English Journal, Vol. 5(1), 290-303. Retrieved from http://eds.a.ebscohost.com/95382057

Peng, G. (2011). On the effectiveness of writing strategies in promoting 13-15 years old Chinese ESL learners' writing ability (Doctoral dissertation). Kristianstad University, Sweden.

Rababah, G. (2003). Communication problems facing Arab learners of English: A personal perspective. TEFL Web Journal, 2(1), 15-30. Retrieved from http:/files.eric.ed.gov/fulltext/ED473079.pdf

Reid, J. M. (1993). Teaching ESL writing. Englewood Cliffs, NJ: Regents/Prentice Hall.

Sadik, A. (2009). Cognitive and metacognitive writing strategies and their relations to writing performance of EFL learners (Unpublished Doctoral Dissertation). Universitas Hasanuddin Makassar, Indonesia.

Setyono, B. (2014). Approaches in teaching writing designed by high school English teachers in Indonesia. International Journal of Sciences: Basic and Applied Research, Vol. 14(1), 477-494. Retrieved from http://gssrr.org/index.php?journal=JournalOfBasicAndApplied

Silva, T. (1990). Second language composition instruction: developments, issues, and directions in ESL. In B. Kroll (Ed.), Second language writing: Research insights for the classroom (pp. 11-23). Cambridge, U.K.; New York: Cambridge University Press.

Sulistyaningsih. (1997). A descriptive study on rhetoric in students' expository essay (Unpublished Master thesis). State University of Malang, Indonesia.

Zamel, V. (1976). Teaching composition in the ESL classroom: What we can learn from research in the teaching of English. TESOL Quarterly, 10, 67-76. DOI: 10.2307/3585940

Zamel, V. (1982). Writing: The process of discovering meaning. TESOL Quarterly, 16(2), 195-209. DOI: $10.2307 / 3586792$ 
Appendix

Interview Questions

1. What is your name?

2. How old are you?

3. How often do you write in English? Why?

4. Describe your learning experience writing English composition?

5. What do you think about writing in English?

6. What do you usually do when you are assigned a topic to write in English? Why?

7. What do you usually do when you run out of ideas while composing? Why?

8. What do you usually do after you finish writing a composition or before you hand it in to the instructor? Why?

9. Did the teacher correct your writing? How?

10. When you have difficulties, do you ask your teacher to help you?

11. What steps/stages do you use when you write?

12. Do you edit and revise your first draft? If yes, how many times, and in what ways.

13. How do you feel about writing in English?

14. Do you feel comfortable when you write in English? If yes, why?

15. Do you like the writing activities your teacher practice? If yes, why?

Source: adapted from Alhosani (2008) 